\title{
The Use of Immunity Doctrine in Commercial Activities in Mesopotamia and Ancient Greece
}

\section{Dodik Setiawan Nur Heriyanto}

\author{
Faculty of Law, \\ Islamic University of Indonesia
}

Doi: 10.2478/ajis-2018-0033

\begin{abstract}
This study traces the history of the formation of immunities concept and its application in commercial activities in ancient Mesopotamia and Greece. The doctrine of immunity is discussed based on the historical process starting from the myth, concept, and its implementation in the commercial/trade activities. By using historical approach, this study shows that in Mesopotamia and Greece, traders or merchants enjoyed absolute immunity due to their position as the representative of their King or polis in which their commercial acts and diplomatic mission were combined. In Mesopotamia, merchants enjoyed the full confidence of the King, and one would not be wrong to suppose that in such enterprises commercial activity and diplomatic mission were combined. Compared to the Mesopotamian practices that granted all traders with the status of immunity from public obligations, in ancient Greece only traders with honorific conditions could enjoy the status of proxenos.
\end{abstract}

Keywords: immunity, commercial activities, history, Mesopotamia, and ancient Greece

\section{Introduction}

None ever found the immunity doctrine when the first time born in history. However, many experts agreed that immunity was born and developed in line with the emergence and development of the power of diplomacy. Moreover, supported by Oppenheim, he considered that diplomacy is an area of study as old as history itself. ${ }^{1}$

Tracing the use of immunity in commercial practice is not easy work. In other side, lot of trusted periodicals explaining the ancient nations did commercial activities. Those periodicals also give the historical's information when simply immunity used as a type of protection during political diplomacy. Such reflected publications influenced this study to keep the original information on how simple protection on trade did by the powerful authority began to developed up and down in the history.

By using historical approach, this study shows that the conception of immunity has begun to be used to protect the merchants in ancient Mesopotamia. After that, the concept of immunity developed by practices in ancient Greece. This development is greatly influenced by the power of trade and political diplomacy.

\footnotetext{
${ }^{1}$ Oppenheim, L. (1965) International Law. UK: Longmann. p.769. Sen, B. (1965) A Diplomat's Handbook. The Hague: Martinus Nijhoff. p.3.
} 


\section{Analysis and Results}

\subsection{Beginning Practice in Mesopotamia}

In ancient history, Mesopotamia was well known as the 'land between the rivers' reflecting their land was widely fertile due to seasonal rains and good for growing crops. ${ }^{2}$ The lack of natural resources urged people of Mesopotamia to make trade to other cities. Trade became integral to the economy, custom, and culture of Mesopotamia. Aware that they were surplus in agricultural products then a vigorous trading system developed. ${ }^{3}$

The third dynasty of Ur $(2112-2004)^{4}$ promoted foreign trade policy while at the same time the King ordered his peoples to increase agricultural productivity. ${ }^{5}$ This dynasty became the capital of Sumer and Akkad. ${ }^{6}$ At that time, merchants were the leading actor of the trade relations. They transported the goods from and to Mesopotamia and other cities even outside the Kingdom's territory, and also mostly made exchange for rare commodities needed by the people. They travelled by donkey caravan, river barges, and sea- going ships to all parts of the Fertile Crescent, Persia, Tilmun, Magan, and Melukka. ${ }^{7}$ They imported copper, precious stones and woods, and ivory $^{8}$, and they also exported agricultural products (such as: barley, wheat, dates, leather and wool), dried fish and goods manufactured from local materials (such as fine woolen textiles, perfurmed ointments and oils). ${ }^{9}$ Cohen argued that merchant groups are culturally distinct, organizationally cohesive, and socially independent from their host communities while maintaining a high level of economic and social ties with related communities who define themselves in terms of the same general cultural identity. ${ }^{10}$

During the Ur period, the majority of the goods they transported were furnished by state (palace or temple) investment and the merchants also carried small quantities of goods on their own behalf. ${ }^{11}$ The nature of trade describe that state was an important customer for the merchant ${ }^{12}$ though their relationship questioned by the history and texts. ${ }^{13}$ However, Karen wrote that merchants at that time were the true agent of state: ${ }^{14}$

\footnotetext{
${ }^{2}$ Mesopotamia's land lies between Tigris and Euphrat's river. The word Mesopotamia comes from the Greek means "the land between two rivers". Kasak, E. \& Veede, R. (2001) Understanding Planets in Ancient Mesopotamia. Electronic Journal of Folklore, Vol.16. [Online] Available at http://haldjas.folklore.ee/folklore (January 21st, 2015). p.7.

${ }^{3}$ Schomp, V. (2004) Ancient Mesopotamia: The Sumerians, Babylonians, and Assyrians. New York: Franklin Watts. pp.9-15.

${ }^{4}$ Gadd, C. J. Babylonia c. 2120 - 1800 B.C. (Chapter XXII). In: I. Edwards, E. S., et.al. (eds.) (1971) The Cambridge Ancient History Volume 1 Part 2: Early History of the Middle East. Cambridge: Cambridge University Press. pp.595-640.

${ }^{5}$ Bertman, S. (2003) Handbook to Life in Ancient Mesopotamia. Oxford: Oxford University Press. p. 109.

${ }^{6}$ The third Dynasty of Ur represents an interesting symbiosis between a "Sumerian" tradition going back to the Presargonic city-states and an "Akkadian" heritage of a large super-regional state. Becker, A. (1985) Neusumerische Renaissance? Wissenschaftliche Untersuchungen zur Philologie and Archäologie. Baghdader Mitteilungen 16. pp. $229-316$.

${ }^{7}$ Alexander, M. W. and Violet, W. (2012) Trade and Traders of Mesopotamian Ur. American Society of Business and Behavioral Sciences, Vol.19 No.1. p.12.

${ }_{8}^{8}$ Ibid.

9 There is still unclear connection that the exported products used in exchange of imported goods for Mesopotamians. McIntosh, Jane. (2008) The Ancient Indus Valley. California: ABC-CLIO. p.188.

${ }^{10}$ Cohen, Abner (1969) Custom and Politics in Urban Africa: A Study of Hausa Migrants in Yoruba Towns. University of California Press. p.266-267.

11 Jane McIntosh. Op. cit., p.191.

12 Ibid. p. 14.

${ }^{13} \mathrm{Ibid}$. See also Powell, M. A. Sumerian Merchants and the Problem of Profit. In J. D. Hawkins (ed.) (1977)

Trade in the Ancient Near East. London: British School of Archeology in Iraq. p.27.

${ }^{14}$ Nemet-Nejat, K. R. (1998) Daily Life in Ancient Mesopotamia. Westport: Greenwood Press. p. 273.
} 
"Texts referred to the same routes used for centuries for transportation of goods, the movement of troops, and the journeys of merchants or diplomatic envoys, who were often the same persons. The Akkadian term showed the wide range of activities of this agents; the Akkadian word could be translated "messenger", "envoy", "ambassador", "diplomat", "deputy", and even "merchant...."

As everybody else working for the third Ur state, merchants enjoyed the status of éren, i.e., state dependents. ${ }^{15}$ Their work for the state entailed the procurement of foreign goods and even more importantly the distribution throughout the state economy of perishables and other commodities that could not efficiently handled by the central redistributive mechanisms held by the state. ${ }^{16}$ Those works seem that state distributed the power in such areas to merchants and as consequence they enjoyed protection at times. ${ }^{17}$ Such protection covered freedom of movement and protection against raids, hold-ups, and robbery. ${ }^{18}$ Beside earned silver ${ }^{19}$, they also receive state funds to acquire foreign goods. ${ }^{20}$ One record, for example, lists thirteen individual or groups of merchants from all over the third Ur state who received amounts of silver for the purpose of acquiring gold. ${ }^{21}$

Merchants enjoyed the full confidence of the King, and one would not be wrong to suppose that in such enterprises commercial activity and diplomatic mission were combined. ${ }^{22}$ This means that merchants enjoy the protection as similar as diplomatic mission while they worked as state's commercial agent and even for their private purpose in business. The protection enjoyed by merchants classified as simply immunity protection since no separation of the use of the privilege as the agent of the state and as private individual. It influenced by their dominant closed relation with the royal institution of third Ur. Eventhough this protection was simply or primitive conception but it was the first basis of protection by the agent of state acting for commercial purposes during the historical timeline.

\subsection{Practice in Greece}

It is quite challenging when tracing the economic activities done by ancient Greece since this site wellknown as a source of philosophical, political, and legal thoughts. Based on anthropological found during the Archaic (776 - 480 BCE) and Classical (776 - 480 BCE) period Greece was actually divided into city-states or 'polis'. ${ }^{23}$ The obvious increase population and expanding territorial occupation had positioned market as fundamental part of Greece's way of living in the past.

${ }^{15}$ Rollinger, R. and UIf, C. (eds.) (2002) Commerce and Monetary Systems in the Ancient World Means of Transmission and Cultural Interaction. Proceedings of the Fifth Annual Symposium of the Assyrian and Babylonian Intellectual Heritage Project, Innsbruck, Austria. p.97.

${ }^{16}$ Ibid.

17 Jane Mclntosh. Loc. cit.

18 Heise, J. (2015) [Online] History of the Bronze Age in Mesopotamia. Available at http://www.sron.nl/ jheise/akkadian/bronze_age.html (January 21st, 2015).

${ }^{19}$ Snell, D. C. (1982) Ledgers and Prices Early Mesopotamian Accounts. Yale Near Eastern Researchers 8 , New Haven, London. p.49.

${ }^{20}$ Van De Mieroop, M. Silver as a Financial Tool in Ancient Egypt and Mesopotamia. In Benholz, P. and Vaubel, R. (eds.) (2014) Explaining Monetary and Financial Innovation. Switzerland: Springer International Publishing. p.26.

${ }^{21}$ Garfinkle, S. J. Silver and Gold: Merchants and the Economy of the Ur III State. In P. Michalowski (ed.) (2008) On Ur III Times: Studies in Honor of Marcel Sigrist. Boston: American Schools of Oriental Research, Boston. pp.63-70.

${ }_{22}^{2}$ Neumann, H. Ur-Dumuzida and Ur-Dun. In Dercksen, J. G. (ed.) (1999) Trade and Finance in Ancient Mesopotamia, Proceedings of the First MOS Symposium, Leiden. p.52.

${ }^{23}$ Greg Anderson argued that polis was neither state-based nor stateless as such, but something in between. Anderson, G. (2009) The Personality of the Greek State. 129 The Journal of Hellenic Studies 1. p.2. 
Agora had built in each polis as public city centre that had major function as internal market. ${ }^{24}$ Products sold in the market commonly came from domestic market and those market mostly limited to local exchanges within the countryside. There was little possibility but demanded import for luxury products from Asia, Africa, and Nothern Europe. ${ }^{25}$

In the ancient Greece, government had no dominancy to the market. The main economic concerns of the governments of the Greek city-states were to maintain harmony within the private economy (make laws, adjudicate disputes, and protect private property rights), make sure that food was available to their citizens at reasonable prices, and obtain revenue from economic activities (through taxes) to pay for government expenses. ${ }^{26}$

The poetry of Hesiod, an $8^{\text {th }} \mathrm{BC}$ poet from Central Greece ${ }^{27}$, reveals the existance of emporoi ${ }^{28}$, traders who hired of others ships for their economic benefits. Reed takes emporoi and naukleroi (traders who owned their own ships for their ventures) in the same group of traders ${ }^{29}$ while the other group consisted people who pursued in trade as complementary living. ${ }^{30}$ Emporoi has some distinct characteristicts such as: carried on interstate trade, relied for much (or probably most) of their livelihood on interstate trade, traveled by sea, traveled in someone else's ship, owned the goods they trade in, and did not produce the goods they trade in. Naukleroi also has only single main characteristic: one who was the owner of a seagoing merchantman. ${ }^{31}$

The earliest written sources of Homer and Hesiod attest to the existence of trade (emporia) and merchants (emporoi) from the 8th century BC, although they often present the activity as unsuitable for the ruling and landed aristocracy. ${ }^{32}$ Those written sources refers to both Emporoi and Naukleroi envolved from being largely agents of aristocrats or part timers to mostly independent professionals. $^{33}$

Most traders in ancient Greece were xenoi rather than metics but not all of them having status as proxenos. ${ }^{34}$ Proxenos is citizen appointed in his own polis to look after affairs of another polis or

${ }^{24}$ See Camp, J. M. (1986) The Athenian Agora: Excavations in the Heart of Classical Athens. London and New York: Thames and Hudson.

${ }^{25}$ Gagarin, M. and Fantham, E. (eds.) (2010) The Oxford Encyclopedia of Ancient Greece and Rome. New York: Oxford University Press. p.306.

26 Hogan, C. M. (2011) Economy of Ancient Greece. [Online] Available from: http://www.eoearth.org/view/article/151946/ [Accessed: October 25th, 2015].

${ }^{27}$ Martin, T. R. An Overview of Classical Greek History from Mycenae to Alexander. [Online] Available from: http://www.perseus.tufts.edu/hopper/text?doc=Perseus\%3Atext\%3A1999.04.0009\%3Achapter\%3D4

[Accessed: October 26th, 2015].

${ }^{28}$ In his poems, Hesiod explains about sailing ships and commerce but this just part-time work of peasants because they could not leaved their farm in a long time. HASEBROEK, J. (1933) Trade and Politics in Ancient Greece. London: Biblo and Tannen Publishers. p.67.

${ }^{29}$ Plato puts both emporoi and neukleroi in similar group for those who wander about in the markets or from town to town, by sea and by land, exchanging money for goods or exhanging money for moneys. Bolkestein, $H$. (1958) Economic Life of Greece's Golden Age. Netherland: E. J. Brill. p.111.

${ }^{30}$ Reed, C. M. (2003) Maritime Traders in Ancient Greek World. Cambridge: Cambridge University Press. p.1011.

${ }^{31}$ Ibid. pp.7-12. The word Naukleroi has direct meaning in commercial activity. See also Finley, M. I. (1935) Emporos, Naukleros, and Kapelos: A Prolegonema to the Study of Athenian Trade. 30 Classical Philology 320. pp.335-336. Merchantman is any non-naval vessel, including tankers, freighters, or cargo ships, but not army ships.

${ }^{32}$ Cartwright, Mark. Trade in Ancient Greece. [Online] Available from: http://www.ancient.eu/article/115/ [Accessed: October 27th, 2015].

33 Ibid.

${ }^{34}$ Proxeny or Proxenia (Greek: $\pi \rho \circ \xi \varepsilon v i ́$ ) in ancient Greece was an arrangement whereby a citizen (chosen by the city) hosted foreign ambassadors at his own expense, in return for honorary titles from the state. The citizen

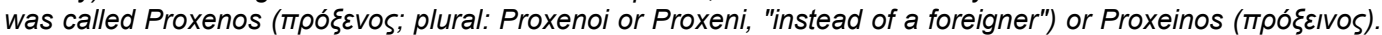
The proxeny decrees, which amount to letters of patent and resolutions of appreciation were issued by one state to a citizen of another for service as proxenos, a kind of honorary consul looking after the interests of the

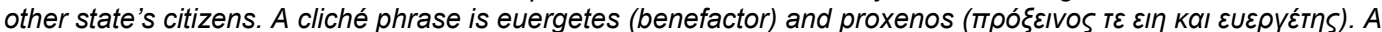
Proxenos would use whatever influence he had in his own city to promote policies of friendship or alliance with 
citizen representing one Greek community in another polis. ${ }^{35}$ Proxenos has special privilege that usually called as proxenia. ${ }^{36}$ Some Emporoi and Naukleroi as benefactors to the Greece community were rewarded the titles of proxenos with proxenos decree and immune from the public obligations. Demetriou (2012) describes this privilege by giving real practice in Rhodes island:

"The grants of proxenia are reminiscent of the honors given by the island of Rhodes to the two residents of Naukratis. One of these inscriptions, dating to 440-411 BC, records the honors given to a man appropriately named Damoxenos (foreigner to the deme), who is described as living in Egypt. The mention of the Hellenion later on in the inscription suggests that this man's residence was probably Naukratis. Damoxenos was named proxenos and euergetes of the Lindians and was also given tax exemption on imports and exports for himself and his descendants both in times of war and peace. The other inscription, slightly later (411-407 BC), gave Pytheas' son, a resident in Egypt from Naukratis, and his descendants, the title of proxenos of All Rhodians. Phyteas' son and his descendants were also given the right to sail in and out of Rhodes both in times of war and peace. Although these two inscriptions are not Attic, they fit into Whitehead's scheme. Their earlier date may explain the fact that the inscriptions explicitly mention that these two men were residents of Naukratis and not Rhodes, where thet were given the title proxenoi. The Rhodian inscriptions also gave the men they honored tax exemption on imports and exports and the right to sail to and from Rhodes at any time. This implies that they were probably emporoi or naukleroi, the same professons as those of the honorees of the Attic inscriptions, and that even though their official residence was Naukratis, they were mobile, as were traders who received the Athenian rewards. The grant og tax exemption on the specific route from Naukratis to Rhodes, even if it was restricted to specific individuals, is similar to the legislation that the Thracian authorities enacted that made several trade routes from Maroneia to Pistiros and from Pistirost o the Belana emporia tax exempt. The recipients of the Athenian honors, however, do not receive tax exemption either on their import sor exports, although their status as proxenoi implied that they received some relief on their residency taxes. In any case, the Attic and Rhodian inscriptions suggest that Athens and Rhodes had similar ways of rewarding their foreign traders: both poleis often granted the status of proxenos to them. If each polis whose traders dealt with a given emporion probably had a proxenos there, then proxenia should be understood as another network that connected various poleis with each other accross the Mediterranean., ${ }^{, 37}$

Compare with Mesopotamian practices that granting all traders with status of immune from public obligation, in Ancient Greece only trader with certain condition got status of proxenos. These proxenos titles were not simple honors with no tangible advantages, as might be inferred from the fact that the polis often added privileges such as ateleia (immunity from public burdens) ${ }^{38}$, asylia (freedom from seizure of one's goods) ${ }^{39}$, and epimeleia (an injunction to the officials of the state to

the city he voluntarily represented. For example, Cimon was Sparta's Proxenos at Athens and during his period of prominence in Athenian politics, previous to the outbreak of the First Peloponnesian War, he strongly advocated a policy of cooperation between the two states. Cimon was known to be so fond of Sparta that he named one of his sons Lacedaemonius. Being another city's Proxenos did not preclude taking part in war against that city, should it break out - since the Proxenos' ultimate loyalty was to his own city. However, a Proxenos would naturally try his best to prevent such a war from breaking out and to compose whatever differences were threatening to cause it. And once peace negotiations were on the way, a Proxenos' contacts and goodwill in the enemy city could be profitably used by his city. The position of Proxenos for a particular city was often hereditary in a particular family. See Thucydides and Crawley, R. (trans.) (2006) The History of the Peloponnesian War. New York: Barnes and Nobles. p.33. Hazel, J. (2002) Who's Who in in the Greek World. New York: Routledge. p.56.

${ }^{35}$ Jact (1984) The World of Athens: An Introduction to Classical Athenian Culture. Cambridge: Cambridge University Press. p.370.

36 Ibid.

${ }^{37}$ Demetriou, D. (2012) Negotiating Identity in the Ancient Mediterranean: The Archaic and Classical Greek Multhiethnic Emporia. Cambridge: Cambridge University Press. p.214.

${ }^{38}$ Harding, P. (ed.) (1985) From the End of the Peloponnesian War to the Batle of Ipsus: Translated Documents of Greece and Rome II. Cambridge: Cambridge University Press. p.178.

${ }^{39}$ Reed, C. M. op.cit. p.xi. 
watch over the proxenos' interests $)^{40}$. Having status as proxenos implied admission to a category of foreigners with privileged status, although the concrete privileges were ill defined. ${ }^{41}$ There are laws regulated the privileges of proxenoi in some poleis but not in all poleis. However this was not always the case, and even when a law existed, furth privileges could be added. Privileges are therefore often mentioned explicitly, although this habit in no way prohibited explicit reference to others that were already attached by law to the titles of proxenos since reference to these as well served to further highlight the polis' liberality. ${ }^{42}$

Occasionally, proxenos were awarded Athenians citizenship but seldom awarded in the fifth BC. ${ }^{43}$ However, Michell (2002) assumed that proxenia and citizenship were incompatible with each other since, it is claimed, a proxenos could not by a definition be a citizen of the state (polis) he was representing:

\begin{abstract}
"It is generally assumed that proxenia and citizenship were incompatible with each other since, it is claimed, a proxenos could not by definition be a citizen of the state he was representing - but we should resist the temptation to make the Athenians this legalistic. Sincet he role of a proxenos was to look after the interests of the honouring state in his natal state, a subsequent grant of citizenship did not disenfranchise him in his own polis or nullify the proxenia. His status as proxenos would be threatened only if he was unable to fulfill his obligation to look after the interets of the awarding state. A good fourth-century example of the compatibility of citizenship and proxenia is given by an inscription honouring a Philes of Rhodes. In the main body of the decree he is wawarded proxenia, while in a rider to the decree he is awarded citizenship. Osborne finds this problematic, assuming that proxenia is 'a privilege clearly incompatible with citizenship', and argues that the rider supersedes the main decree. Although it is clear that Philes was in Athens at the time of the awards, there is no reason to assume that he remained in Athens or that he did not return to his native Rhodes to excercise his proxenia on Athen's behalf while remaining an honorary Athenian citizen. In this case, the citizenship would have emphasised his rights in Athens and given him status there, but the proxenia would have emphasised his duties to the Athenians when in his natal state. ${ }^{, 44}$
\end{abstract}

Burke has pointed out the fact that from "the late fifth and fourth $B C$ there are a number of instances where Athens and other states did designate as proxenoi men actively involved in maritime trade". ${ }^{45}$ An inscription quoted by Kloppenborg and Ascough (2011) provides an example of the designation of a foreigner as a proxenos and their honors as stated as follows:

40 There had a clause in specific enabling the proxenos to seek redress in Athens at the court of the Polemarch. Low, P. (2008) Athenian Empire. Edinburgh: Edinburgh University Press. p. 136.

${ }^{41} \mathrm{lbid}$. The proxenos decrees were also provided certain privileges such as: safeguarding the proxenos and his families from civil wrong, exemptions from all or specific taxes (ateleia), the right to own real property at Athens (enktesis), the right to sail and carry on trade in certain areas under Athenian blockade, compensation for losses or special payments, exemption from taxes on the import of shipbuilding materials, the establishment of a special commission to examine a case brought by the proxenos, guarantees that land or moneys will be inviolable.

${ }^{42}$ The tile proxenos normally denoted benefactions performed for individuals who resided in or were whort-term visitors to the proxenos' polis. It is different with the title of euergetes which emphasized benefactions performed for an entire community that was nor the euergete's polis. A proxenos might also perform (or have performed) services for the entire polis from which he received the title - the title implied that its bearer was a benefactor of the entire city - and these services could be rendered in the polis that grated the title, rather than in the proxenos' own polis. But the purpose of mentioning both titles was to highlight the two directions in which benefactions could be oriented (toward persons in the benefactor's polis and those in another place) and the two levels at which it was possible to act (the individual and the communal). Gygax, M. D. (2016) Benefaction and Rewards in the Ancient Greek City. Cambridge: Cambridge University Press. p.110.

43 Ibid.

${ }^{44}$ Mitchell, L. G. (2002) Greeks Bearing Gifts: The Public Use of Private Relationships in the Greek World. Cambridge: Cambridge University Press. pp.39-40.

${ }^{45}$ Burke, E. M. (1992) The Economy of Athens in the Classical Era: Some Adjustments to the Primitivist Model. 122 Transactions of the American Philological Association 199. p.207. 
"... of the presidents, Epameinon has put to a vote (the motion) that NN son of NN of the deme Anagyrous proposed: Whereas the shippers and merchants have declared Apollonides son of Demetrios of Sidon to be a good man and well-intentioned toward the people of Athens, the People (demos) resolved to commend Apollonides son of Demetrios of Sidon and to crown him with a golden crown of the value of 1000 drachmae, on account of the excellence and good will that he shows to the people of Athens: and he and his children shall be (designated as) proxenoi and benefactors (euergetes) of the people of Athens; and in accordance with the law he shall have possession (enktesis) of property and a house. Lett he secretary of the Council inscribe this decree on a stele and set it up on the Acropolis and lett he treasurer of the People say for the inscribing of the stele (up to?) $x$ drachmae, from the expenses designated for (the inscribing) of decrees. ${ }^{, 46}$

The interaction between public and private aspecs in Greek political relationships is fascinating to study: when the polis behaved as a corporate body, it often assumed models for relationships which to modern sensibilities could be considered more appropriate to personal activities than for impersonal state relations. However, the corporate polis could appeal to ties of kinship, form proxenia relationships as if they were xenia, and award citizenship in order to elicit strong bonds of responsibility to the state. All of these relationshops implied and appealed to duties and obligations that were more natural to personal relationships. Even if it was manufactured or artificial, this call to loyalty and duty was still strong: kin should help kin, proxenoi should help benefactors, 'citizens should help fellow citizens. How seriously this responsibility was taken depended on the individual and on individual situations, but it was part of what made these relationships work, and if it was rejected or ignored it could lead to the failure of the relationship with all the (real or assumed) disappointment and anger that entailed. ${ }^{47}$

\section{Conclusion}

In Mesopotamia, merchants (with no certain conditions) received immunity protection from the King while they worked as state's commercial agent and even for their private business. However, in ancient Greece, proxenos - (immunity from public burderns and freedom from seizure of one's goods) were granted to trader only if they met certain condition which they must provide any tangible advantages to the community. Both of the privilege were absolute in the practice at that time.

${ }^{46}$ Kloppenborg, J. S. and Ascough, R. S. (2011) Attica, Central Greece, Macedonia, Thrace. New York: Walter de Gruyter. pp.205-206.

${ }^{47}$ Mitchell, L. G. op.cit. p.40. 